\title{
MALFORMATIONS INDUCED BY SODIUM ARSENATE
}

\author{
VERGIL H. FERM AND STANLEY J. CARPENTER \\ Department of Anatomy, Dartmouth Medical School, \\ Hanover, New Hampshire 03755, U.S.A.
}

(Received 4th April 1968)

\begin{abstract}
Summary. The intravenous injection of $20 \mathrm{mg} / \mathrm{kg}$ of sodium arsenate into pregnant golden hamsters on the 8th day of gestation causes a high incidence of exencephaly in embryos recovered 4 to 5 days later. The effect of arsenic seems to be site-specific and may be related to damage of the embryonic mesenchyme.
\end{abstract}

The relationship of arsenic administered to pregnant animals and the effect of this metal upon the embryonic system has not been completely investigated. Most studies on this subject have related to the use of organic arsenicals as anti-syphilitic therapy during pregnancy. No evidence exists in mammals for any teratogenic effect of arsenic upon developing embryos although in the chick a direct teratogenic effect has been reported (Ancel, 1947). In mice, the intravenous injection of organic arsenicals results in the apparent storing of this metal in the placenta and a negligible transmission to the foetal tissues (Lebedewa, 1934). Likewise, during the last third of pregnancy in the rabbit, the arsenic is also stored in the foetal portion of the placenta but, as term approaches, increasing amounts of arsenic are found within the foetal tissues (Snyder \& Speert, 1938). Eastman (1931) has reported on the use of organic arsenicals in human pregnancies and presented data which suggest that arsenic is rapidly and effectively stored within the foetal portion of the placenta and slowly released into the foetal circulation. This may account for the markedly effective treatment of congenital syphilis with these compounds.

None of these mammalian studies have reported on the possible embryocidal or teratogenic effect of arsenic upon earlier embryonic stages. Previous studies in this laboratory have shown that, in the golden hamster, site-specific congenital malformations can be induced with lead (Ferm \& Carpenter, 1967a) or cadmium (Ferm \& Carpenter, 1967b) injected into the pregnant animal during the critical stages of embryonic development. This paper reports on the marked teratogenic and embryocidal effect of inorganic arsenic administered in the form of sodium arsenate in the golden hamster.

Virgin female golden hamsters (Cricetus auratus) were mated with male hamsters. The day following the evening of mating was designated as the lst day of gestation. On the 8th day of gestation the pregnant hamsters were injected into the lingual vein (Ferm, 1967a) with $5 \mathrm{mg} / \mathrm{kg}$ or $20 \mathrm{mg} / \mathrm{kg}$ of sodium arsenate made up in distilled water. Control animals received distilled water only. The volume of the injected solution was standardized at $1.0 \mathrm{ml} /$ 
$100 \mathrm{~g}$ of body weight. On Days 12, 13 or 14 of gestation, the animals were killed and the foetuses recovered. Resorption sites were counted and recorded, and the surviving embryos were examined for gross malformations. The placentae were prepared for histological examination.

Sodium arsenate, when injected into pregnant hamsters on the 8th day of gestation, produces a specific malformation of the head, exencephaly. The dosage level appears to be critical since $5 \mathrm{mg} / \mathrm{kg}$ induces no malformations while a dose of $40 \mathrm{mg} / \mathrm{kg}$ kills all embryos in utero. The exencephalic lesion is markedly consistent and specific and often within a single litter a majority of the survivors will show a strikingly similar defect (Plate 1). Secondary effects of this nervous system lesion included occasional bulging of the eyeballs and a relative protrusion of the tongue and mandible similar to that seen in hypervitaminosis-A-treated animals (Marin-Padilla \& Ferm, 1965). No other gross external malformations were noted in other organ systems. The maternal animals tolerated all dose levels of arsenic used in these experiments very well. Maternal weight gain was normal. Histological examination of the placental membranes revealed no abnormality.

TABLE 1

EMBRYOCIDAL AND TERATOGENIC EFFECT OF SODIUM ARSENATE IN THE HAMSTER

\begin{tabular}{l|c|c|c|c|c}
\hline \multicolumn{1}{c|}{ Dose } & $\begin{array}{c}\text { No. of } \\
\text { mothers }\end{array}$ & $\begin{array}{c}\text { No. of } \\
\text { gestation } \\
\text { sacs }\end{array}$ & $\begin{array}{c}\text { No. of live } \\
\text { embryos } \\
\text { recovered }\end{array}$ & $\begin{array}{c}\text { No. of } \\
\text { resorbed or } \\
\text { dead embryos }\end{array}$ & $\begin{array}{c}\text { No. of } \\
\text { embryos } \\
\text { malformed }\end{array}$ \\
\hline $\begin{array}{l}\text { Controls } \\
\text { (distilled water) }\end{array}$ & 10 & 136 & 130 & 6 & 0 \\
$\begin{array}{l}\mathrm{Na} \text { arsenate, } \\
5 \mathrm{mg} / \mathrm{kg}\end{array}$ & 3 & 36 & 30 & 6 & 0 \\
$\begin{array}{l}\mathrm{Na} \text { arsenate, } \\
20 \mathrm{mg} / \mathrm{kg} \\
\mathrm{Na} \text { arsenate, } \\
40 \mathrm{mg} / \mathrm{kg}\end{array}$ & 18 & 255 & 166 & 89 & 109 \\
\hline
\end{tabular}

* All resorbed-no malformation study possible.

Exencephalic lesions have also been produced in the hamster by treating the pregnant mothers with vitamin A (Marin-Padilla \& Ferm, 1965) and dimethylsulphoxide (Ferm, 1967b). Both of these teratogens have a direct effect on embryonic mesenchyme causing necrosis and collapse of the mesodermal cells with a consequent lack of development of the cranium and an unprotected neural tube (Marin-Padilla, 1966a, b). In this respect it is of interest to note that chick embryonic mesenchymal cells grown in tissue culture demonstrate a marked growth suppression when exposed to dilute concentrations of sodium arsenite (Wilson, 1922). Furthermore, Ancel (1946-47) has shown the teratogenic effect of disodium methylarsenate in chick embryos and attributes the spina bifida defect to be the result of specific damage to the chorda mesoderm.

While the data on the permeability of the placenta to arsenic compounds suggest a slow penetration most of them were concerned with the permeability 


\section{PLATE 1}

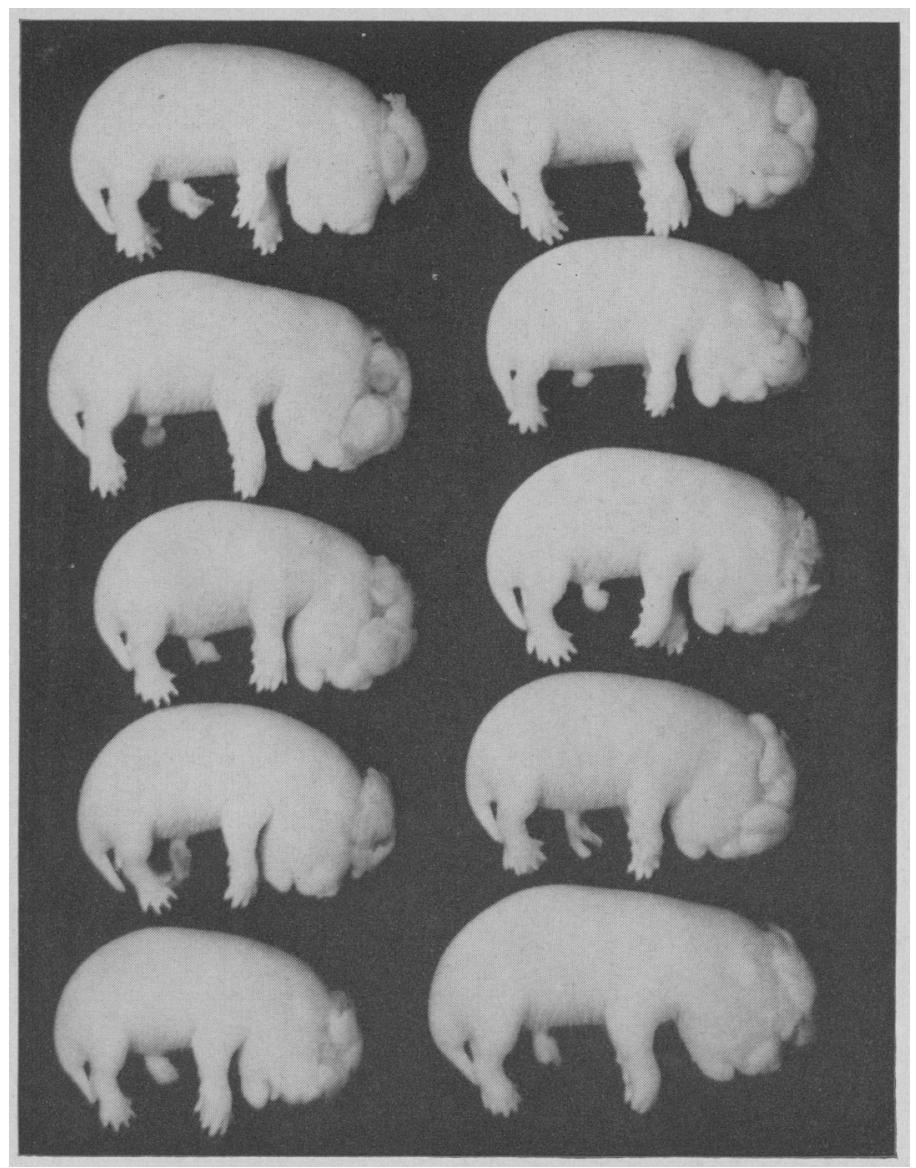

Thirtcen-day-old littermates from female hamster injected with $20 \mathrm{mg} / \mathrm{kg}$ of sodium arsenate on the 8th day of gestation. All foetuses show the same degree of excncephaly. $\times 2$. 
of organic arsenicals. Studies on radio-active inorganic arsenites have shown that a large proportion of this ion is excreted as arsenate in the urine and that these ions distribute rapidly and fairly uniformly into virtually all of the major tissues of the body (Mealey, Brownell \& Sweet, 1959). The possibility remains, however, that the teratogenic action of arsenic may be due to some effect on the maternal system or perhaps an effect on placental permeability.

It is also of interest to note that many compounds which are carcinogenic also have teratogenic properties (DiPaolo \& Kotin, 1966). In this respect the relationship of arsenic to multiple malignant tumours of the skin and viscera is well known (Sommers \& McManus, 1953). Arsenic may affect cell mitosis, for one of its first observable cellular effects is on the nucleus where it causes a scattering of mitotic chromosomes (Limarzi, 1943). These abnormal mitotic figures are especially prevalent in arsenic-induced changes on skin leading to skin carcinomas. Arsenic combines with sulphydryl groups in tissues possibly interfering with pyruvate-oxidase activity. This perhaps explains the effect of arsenate on enzymatic depolymerizations of ribonucleic acid. Further studies on this interesting relationship are indicated.

We would like to acknowledge support from the National Institutes of Health, Grants HD 02616 and GM 10210.

\section{REFERENCES}

Ancer, P. (1946-47) Recherche expérimentale sur le spina bifida. Archs Anat. microsc. Morph. exp. 36, No. 1,45 .

Ancel, P. (1947) Recherche sur la réalisation expérimentale de la celosomie. Arch. Anat. 30, 6.

DiPaolo, J. A. \& Kotin, P. (1966) Teratogenesis-oncogenesis: A study of possible relationships. Archs Path. 81, 3.

Eastman, N. J. (1931) The arsenic content of the human placenta following arsphenamine therapy. Am. F. Obstet. Gynec. 21, 60.

FERM, V. H. (1967a) The rapid detection of teratogenic activity. Lab. Invest. 14, 1500.

FERM, V. H. (1967b) Congenital malformations induced by dimethyl sulphoxide in the golden hamster. 7. Embryol. exp. Morph. 17, 49.

FERM, V. H. \& CARPENTER, S. J. (1967a) Developmental malformations resulting from the administration of lead salts. Exp. molec. Path. 7, 208.

Ferm, V. H. \& Carpenter, S. J. (1967b) Teratogenic effect of cadmium and its inhibition by zinc. Nature, Lond. 216, 1123.

LEBEDEWA, VoN M. N. (1934) Über den Übergang chemotherapeutischer Verbindungen aus dem Organismus der Mutter in den Fetus. Zentbl. Gynäk. 58, 1449.

Limarzi, L. R. (1943) The effect of arsenic (Fowler's solution) on erythropoiesis: A contribution to the megaloblast-normoblast problem. Am. F. med. Sci. 206, 339.

Marin-Padilta, M. (1966a) Mesodermal alterations induced by hypervitaminosis A. F. Embryol. exp. Morph. 15, 261.

Marin-Padilla, M. (1966b) Mesodermal alterations induced by dimethylsulfoxide. Proc. Soc. exp. Biol. Med. 122, 717.

Marin-Padilla, M. \& Ferm, V. H. (1965) Somite necrosis and developmental malformations induced by vitamin A in the golden hamster. F. Embryol. exp. Morph. 13, 1.

Mealey, J., JR, Brownell, G. L. \& Sweet, W. H. (1959) Radioarsenic in plasma, urine, normal tissues, and intracranial neoplasms. Arch. Neurol. Psychiat. 81, 310.

SNyder, F. F. \& SPEert, H. (1938) The placental transmission of neoarsphenamine in relation to the stage of pregnancy. Am. 7. Obstet. Gynec. 36, 579.

Sommers, S. C. \& McManus, R. G. (1953) Multiple arsenical cancers of skin and internal organs. Cancer, 6, 347.

WiLson, J. L. (1922) Tolerance and acquired tolerance of the mesenchyme cells in tissue-cultures for copper sulphate and sodium arsenite. Bull. Fohns Hopkins Hosp. 33, 375. 